\title{
Histone H1.4
}

National Cancer Institute

\section{Source}

National Cancer Institute. Histone H1.4. NCI Thesaurus. Code C115355.

Histone H1.4 (219 aa, 22 kDa) is encoded by the human H1-4 gene. This protein is involved in chromosome compaction. 